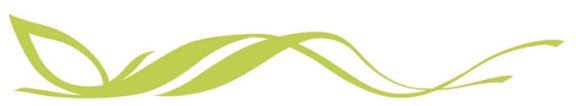

COMMUNICATIONS

EARTH\&ENMRONMENT

ARTICLE

https://doi.org/10.1038/s43247-020-00030-5 OPEN

\title{
Acceleration of ocean warming, salinification, deoxygenation and acidification in the surface subtropical North Atlantic Ocean
}

\author{
Nicholas Robert Bates (1) ${ }^{1,2 凶}$ \& Rodney J. Johnson ${ }^{1}$
}

Ocean chemical and physical conditions are changing. Here we show decadal variability and recent acceleration of surface warming, salinification, deoxygenation, carbon dioxide $\left(\mathrm{CO}_{2}\right)$ and acidification in the subtropical North Atlantic Ocean (Bermuda Atlantic Time-series Study site; 1980s to present). Surface temperatures and salinity exhibited interdecadal variability, increased by $\sim 0.85^{\circ} \mathrm{C}$ (with recent warming of $1.2^{\circ} \mathrm{C}$ ) and 0.12 , respectively, while dissolved oxygen levels decreased by $\sim 8 \%$ ( $2 \%$ per decade). Concurrently, seawater DIC, $\mathrm{fCO}_{2}$ (fugacity of $\mathrm{CO}_{2}$ ) and anthropogenic $\mathrm{CO}_{2}$ increased by $\sim 8 \%, 22 \%$, and $72 \%$ respectively. The winter versus summer $\mathrm{fCO}_{2}$ difference increased by 4 to $8 \mu$ atm decade ${ }^{-1}$ due to seasonally divergent thermal and alkalinity changes. Ocean $\mathrm{pH}$ declined by 0.07 ( 17\% increase in acidity) and other acidification indicators by $\sim 10 \%$. Over the past nearly forty years, the highest increase in ocean $\mathrm{CO}_{2}$ and ocean acidification occurred during decades of weakest atmospheric $\mathrm{CO}_{2}$ growth and vice versa.

\footnotetext{
${ }^{1}$ Bermuda Institute of Ocean Sciences (BIOS), 17 Biological Lane, St. Georges GE01, Bermuda. ${ }^{2}$ Department of Ocean and Earth Science, University of

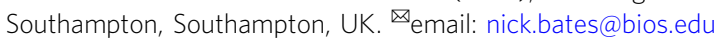


$\mathrm{R}$ ecent acceleration of changes in ocean physics and chemistry since the $1980 \mathrm{~s}$ is demonstrated at two sustained open-ocean hydrographic stations in the North Atlantic Ocean near Bermuda. Of these two time-series sites, Hydrostation $\mathrm{S}$ (formerly known as the Panulirus site) is the oldest, located $\sim 25$ $\mathrm{km}$ southeast of Bermuda at $32^{\circ} 10^{\prime} \mathrm{N}, 64^{\circ} 30^{\prime} \mathrm{W}$, and consists of repeat biweekly hydrographic observations of temperature, salinity and dissolved oxygen (DO) conducted through the water column since $1954^{1,2}$. The Bermuda Atlantic Time-series Study (BATS) site is located $\sim 80 \mathrm{~km}$ southeast of Bermuda $\left(31^{\circ} 40^{\prime} \mathrm{N}\right.$, $\left.64^{\circ} 10^{\prime} \mathrm{W}\right)^{3}$. It consists of a comprehensive monthly sampling of the physics, chemistry and biology of the entire water column commencing in October $1988^{4-7}$, and one of only a handful of ship-based biogeochemical time-series sites remaining in the global ocean ${ }^{7}$. The BATS-hydrostation S time-series represent the two longest records in the global open ocean of warming, salinification, deoxygenation and changes in ocean carbon dioxide $\left(\mathrm{CO}_{2}\right)$-carbonate chemistry that drives ocean acidification $(\mathrm{OA})$. Observations over the past 40 years in the subtropical gyre of the North Atlantic Ocean allow for examination of variability and the trends of ocean change which critically underpin future assessment and prediction. BATS-Hydrostation S time-series data also provide partial support for the findings of a recent study indicating that the highest increases in ocean $\mathrm{CO}_{2}$ and $\mathrm{OA}$ occur during decades of weakest atmospheric $\mathrm{CO}_{2}$ growth and vice versa $^{8}$. Here, we focus on surface/mixed layer changes while examination of variability and trends in deeper waters is the subject of other studies.

The emissions of anthropogenic $\mathrm{CO}_{2}$ to the atmosphere due to fossil fuel use, cement manufacture and land-use changes ${ }^{9}$ have increased rapidly over the last decade ${ }^{10}$. While anthropogenic $\mathrm{CO}_{2}$ accumulates in the atmosphere, it is also taken up by the terrestrial biosphere and oceans ${ }^{11}$. The annual global ocean uptake is estimated ${ }^{10,12-14}$ at $1.4-2.6 \mathrm{PgC} \mathrm{yr}^{-1}\left(\mathrm{Pg}=10^{15} \mathrm{~g}\right)$ at present, with annual rates of the ocean $\mathrm{CO}_{2}$ sink increasing with time $^{13}$, with the cumulative total global ocean uptake of anthropogenic $\mathrm{CO}_{2}$ since pre-industrial times estimated at $120-150 \mathrm{Pg}$ $\mathrm{C}^{12-14}$. The range of global ocean anthropogenic $\mathrm{CO}_{2}$ uptake reflects the different year of the study and evolving data-driven knowledge about the oceans. Ocean uptake of anthropogenic $\mathrm{CO}_{2}$ and seawater chemistry changes such as the reduction in seawater $\mathrm{pH}$, and saturation states for calcium carbonate $\left(\mathrm{CaCO}_{3}\right)$ minerals (i.e., $\Omega$ ) such as calcite $\left(\Omega_{\text {calcite }}\right)$ and aragonite $\left(\Omega_{\text {aragonite }}\right)$ is termed ocean acidification $(\mathrm{OA})^{15}$. It has likely problematic consequences for marine organisms and ecosystems that are, as yet, poorly understood ${ }^{16}$.

In addition, the decrease in ocean DO concentration ${ }^{17}$, a process termed "ocean deoxygenation (ODO)"18,19, is a global environmental issue that has profound future implications for the status of the oceans ${ }^{20,21}$. The emerging contemporary narrative about ODO relates to its coupling with other global environmental changes such as ocean warming and $\mathrm{OA}^{21}$. Oceanic DO is highly sensitive to solubility effects ${ }^{22}$, and thus in turn to ocean physics and air-sea exchange, and long-term drivers such as climate change, stratification and ocean primary production ${ }^{17-21,23}$. A broader environmental context for this study is that there are complex interactions between OA, ODO, ocean biogeochemical cycling, and ocean biology, including microbial pathways ${ }^{24}$ to zooplankton ${ }^{25}$, and expansion of oxygen minimum zones ${ }^{26,27}$. Careful and critical evaluation of such synergistic global environmental drivers is warranted ${ }^{28}$.

\section{Ocean sampling and methods}

The Hydrostation $S$ dataset represents more than 1381 cruises undertaken during the 1954-2020 period, while the BATS dataset represents more than 450 cruises from October 1988 to the end of 2019. Sampling and analytical methods are detailed in the "Methods" section (Supplemental Materials). Measurements of seawater $\mathrm{CO}_{2}$-carbonate chemistry include those of dissolved inorganic carbon (DIC), and total alkalinity (TA) since 1983 (1983-1988, Hydrostation S; 1988-present, BATS), with detailed sampling protocols, analytical approaches and the computation of other parameters such as $\mathrm{pH}$ and $p \mathrm{CO}_{2}$ described in the "Methods" section. DIC and TA data are also normalised to a salinity of 36.6 (mean value in the Sargasso Sea) to remove the influence of evaporation and precipitation, and denoted as $\mathrm{nDIC}$ and nTA, respectively.

The suite of seawater $\mathrm{CO}_{2}$-carbonate parameters (i.e., $f \mathrm{CO}_{2}$, $p \mathrm{CO}_{2}, \mathrm{pH}, \Omega_{\text {calcite }}$ and $\Omega_{\text {aragonite, }}$ Revelle factor) are determined for each sample using DIC and TA at in situ temperature and salinity (see "Methods"). $\mathrm{pH}, \Omega_{\text {calcite, }}$ and $\Omega_{\text {aragonite }}$ in seawater are dimensionless and $\mathrm{pH}$ is expressed on the total scale.

Seasonally detrended anomalies of physical and chemical properties are shown to illustrate changes over time (Figs. 1 and 2) with trend analyses summarised in Table 1a for the past 40 years, and for the decades of the 1980s, 1990s, 2000s and 2010s. It is important to note that while surface data are shown and detailed here, seasonal variability and trends in the mixed layer are nearly identical to surface data. A tracer, TrOCA (Tracer combining Oxygen, inorganic Carbon and total Alkalinity) ${ }^{29}$ is used to test

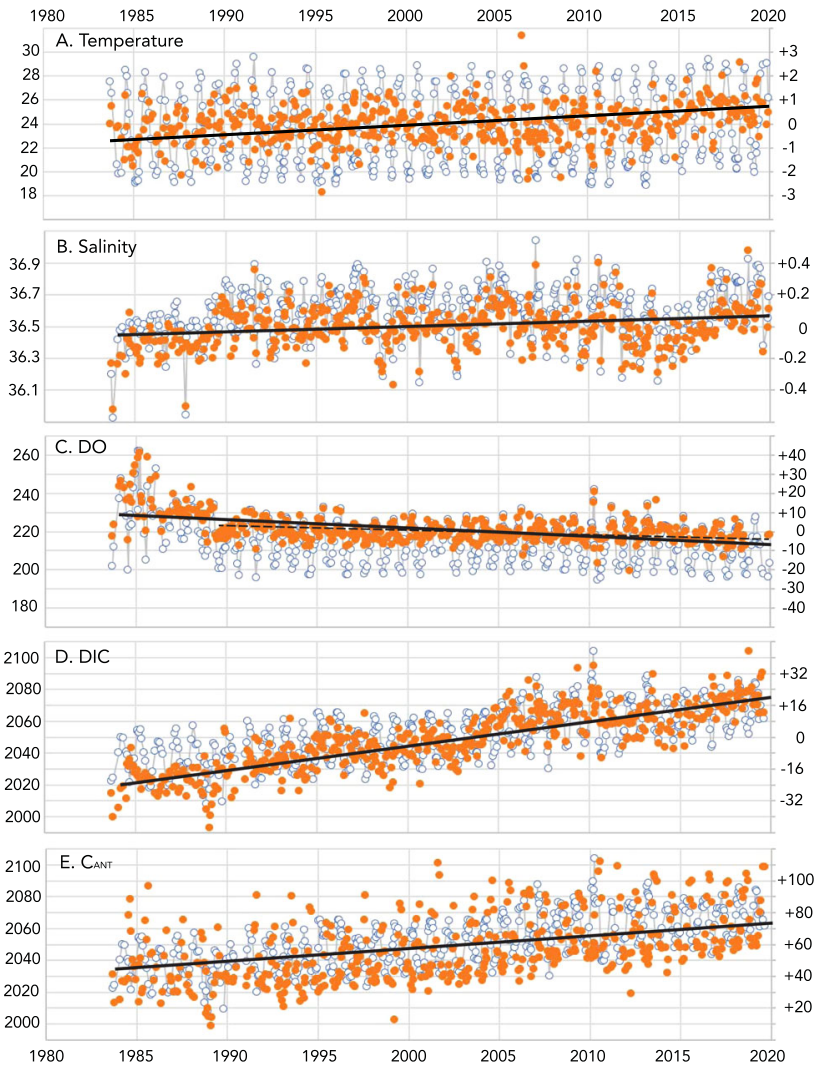

Fig. 1 Hydrographic and seawater $\mathrm{CO}_{2}$-carbonate properties at the BATS site (1988-present) with earlier data (1983-1988) from Hydrostation S. Observed data (left vertical axis; open blue symbols) and anomalies (right vertical axis; orange symbols) are shown. Regression lines are from anomaly data plotted in the right vertical axis and given in Table 1. a Surface temperature and anomalies $\left({ }^{\circ} \mathrm{C}\right)$. b Surface salinity and anomalies. c Surface dissolved oxygen (DO) and DO anomalies ( $\mu$ moles $\mathrm{kg}^{-1}$ ); the dashed line shows the trend from 1990. d Surface DIC and salinity normalised DIC ( $\mathrm{nDIC}$; $\mu$ moles $\mathrm{kg}^{-1}$ ). e $\mathrm{nDIC}$ and $\mathrm{C}_{\mathrm{ANT}}$ values $\left(\mu\right.$ moles $\mathrm{kg}^{-1}$ ). 


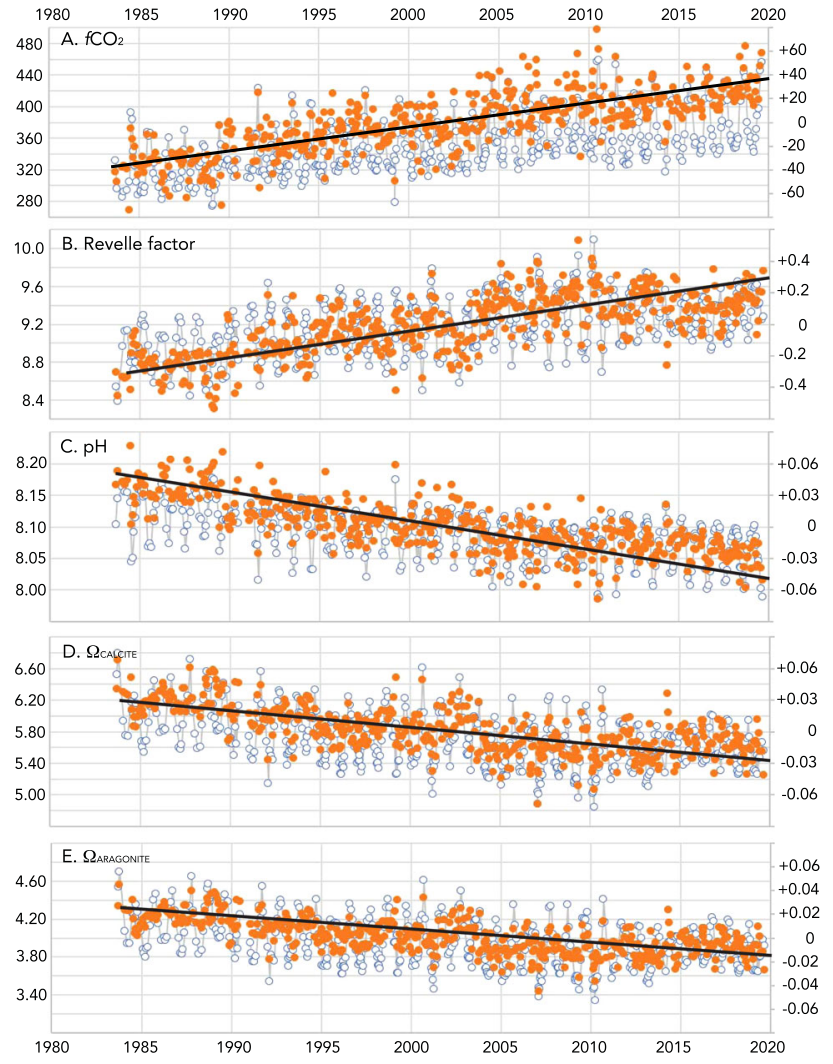

Fig. 2 Hydrographic and seawater $\mathrm{CO}_{2}$-carbonate properties at the BATS site (1988-present) with earlier data (1983-1988) from Hydrostation $S$. Observed data (left vertical axis; open blue symbols) and anomalies (right vertical axis; orange symbols) are shown. Regression lines are from anomaly data plotted in the right vertical axis and given in Table 1. a Surface $\mathrm{fCO}_{2}$ and anomalies ( $\left.\mu \mathrm{atm}\right)$. b Surface revelle factor $(\beta)$ and anomalies. c Surface pH and anomalies. d Surface $\Omega_{\text {calcite }}$ and anomalies. e Surface $\Omega_{\text {aragonite and anomalies. }}$

the evidence for drivers of ocean seawater $\mathrm{CO}_{2}$-carbonate changes, and the decadal variability in global ocean carbon uptake $^{8,30}$.

\section{Results}

Surface ocean warming and salinification. Menzel and Ryther ${ }^{1}$ first documented seasonal cycles of the local convective mixed layer with subsequent papers improving our understanding of the year-to-year and multi-decadal variability of the physical seasonality of the subtropical gyre and relationships to climate drivers $^{3,4,6}$. The Sargasso Sea exhibits a seasonal sea surface temperature variation of $\sim 9-11^{\circ} \mathrm{C}$ (Fig. 3a) with higher surface salinities occurring in wintertime and freshening during the summertime, and low salinity events occasionally apparent (Fig. 3c).

Over the past nearly 40 years (1983-2019), surface temperatures have increased by $0.85 \pm 0.12{ }^{\circ} \mathrm{C}$ (Table 1a; Figs. 1a and $3 \mathrm{~b}$ ). The summer surface temperatures have increased at a higher rate than winter (i.e., $0.26 \pm 0.01^{\circ} \mathrm{C}_{\text {year }}{ }^{-1}$ compared to $0.10 \pm 0.01^{\circ} \mathrm{C}$ year $^{-1}$; Table 1a; note that winter rates are not statistically significant). During the same period, surface salinity also increased by $\sim 0.11 \pm 0.02$ (Table 1a; Fig. 1b), Importantly, these data show evidence of decadal variation in Table 1 . Trend analysis of temperature, salinity, oxygen and ocean $\mathrm{CO}_{2}$-carbonate chemistry from the BATS site (1988-2018; Hydrostation S data from 1983 to 1988 ) is included (see also Table 1 b). Intermediate and deep water variability and trends (including warming and cooling, and freshening) is the subject of a future comprehensive treatment, with, for example, warming below the mixed layer at $300 \mathrm{~m}$ at $\sim 0.8^{\circ} \mathrm{C}$ over the past three decades.

In the 1990s and 2000s, no significant trends in surface temperature and salinity were observed (Table 1a). In contrast, warming and salinification occurred during the 1980s and 2010s (Fig. 1a, b). In the 1980s, salinity increased by 0.27 (Table 1a) associated with the 1989-1990 transition from lower to higher salinity in the subtropical gyre (Fig. 3c, d). During the last decade (2010-2019), rapid warming of $1.18^{\circ} \mathrm{C}$ and salinification of 0.14 has occurred. Temperature and salinity trends go back to 1954 (Table $1 \mathrm{~b}$ ). The warming of $1.18^{\circ} \mathrm{C}$ in the last decade may at first appear inconsistent with overall warming of $\sim 0.85 \pm 0.12^{\circ} \mathrm{C}$ over the past 40 years. The longer trend estimate since 1983 reflects periods of interannual/decadal warming and cooling (e.g., the decades of the 1990s and 2000s had no statistical change) with overall warming since the early 1980s.

Surface ocean deoxygenation. The upper-ocean record of DO shows an overall decline of $\sim 17.8 \pm 2.4 \mu$ moles $\mathrm{kg}^{-1}$ over the past 40 years (Table 1a; Fig. 1c), with short-term year-to-year variability (Fig. 3e, f). The longer-term data represents a loss of DO of $\sim 8.1 \%$ or $\sim 2 \%$ per decade. The trend of DO decline in the Sargasso Sea since the 1980s is in the range shown for global ODO rates of $\sim 0.3$ to $\sim 0.7 \mu$ moles $\mathrm{kg}^{-1}$ year -1 ( 3-7 $\mu$ moles $\mathrm{kg}^{-1} \mathrm{dec}-$ $\left.\mathrm{ade}^{-1}\right)$ in the thermocline $\mathrm{e}^{31,32}$.

Apparent oxygen utilisation (AOU) represents the difference between measured oxygen concentration and oxygen concentration at saturation in seawater with the same physical and chemical properties. AOU, as a calculated parameter ${ }^{22}$, offers a few clues as it reflects changes in oxygen due to the combined effect of biological processes such as primary production and respiration ${ }^{32}$, but also diffusion, circulation, and ventilation ${ }^{19}$. Here, the contribution of nitrification and denitrification to AOU is considered minor in surface waters. The trend in AOU in the upper $500 \mathrm{~m}$ is about $-0.54 \mu$ moles $\mathrm{kg}^{-1}$ year ${ }^{-1}$, which is slightly higher than the contemporaneous decrease in DO (Table 1a).

The cause for deoxygenation of the Sargasso Sea over the past 40 years appears only partly due to solubility changes associated with warming. Given the ocean warming observed in the Sargasso Sea (Table 1a), we estimate that the warming impact on DO solubility ${ }^{16}$ would likely have contributed to about $13 \%$ of the total decline of DO over the past nearly 40 years. The remaining deoxygenation $(\sim 87 \%)$ must result from the combined effect of changes in ocean biology and physics. Recent warming in the 2010 s of $1.18{ }^{\circ} \mathrm{C}$ contributed about $18 \%$ of the concurrent decline in DO in that decade. From 1988 to 2017, open-ocean chlorophyll biomass $\left(\sim+22 \%\right.$ per decade $\left.{ }^{33}\right)$ and rates of in situ primary production observed offshore at BATS increased ${ }^{33}$. Coccolithophore (i.e., calcifying phytoplankton) biomass has increased at BATS ${ }^{34}$ and over the entire subtropical gyre of the North Atlantic Ocean, but it is typically a small $(<10 \%)$ contributor to primary production. Furthermore, low nitrate values in the mixed layer have doubled (i.e., an increase of $\sim 0.25$ umoles $\mathrm{kg}^{-1}$ ) over the past two and a half decades while suspended particulate organic matter and dissolved organic carbon have increased by $\sim 30 \%$ and $2 \%$ per decade, respectively ${ }^{33}$. Other studies indicate that the nutrient stream supporting production in the subtropical North Atlantic has reduced ${ }^{35}$. These puzzles are not addressed here, but likely includes the loss of oxygen from the surface ocean due to gas flux, and perhaps supplies of new nitrogen sources from nitrogen fixation and dissolved organic nitrogen. 
Table 1 Trend analysis of physical properties, seawater $\mathrm{CO}_{2}$-carbonate chemistry, and ocean acidification indicators at the BATS-Hydrostation S site from 1983 to 2020.

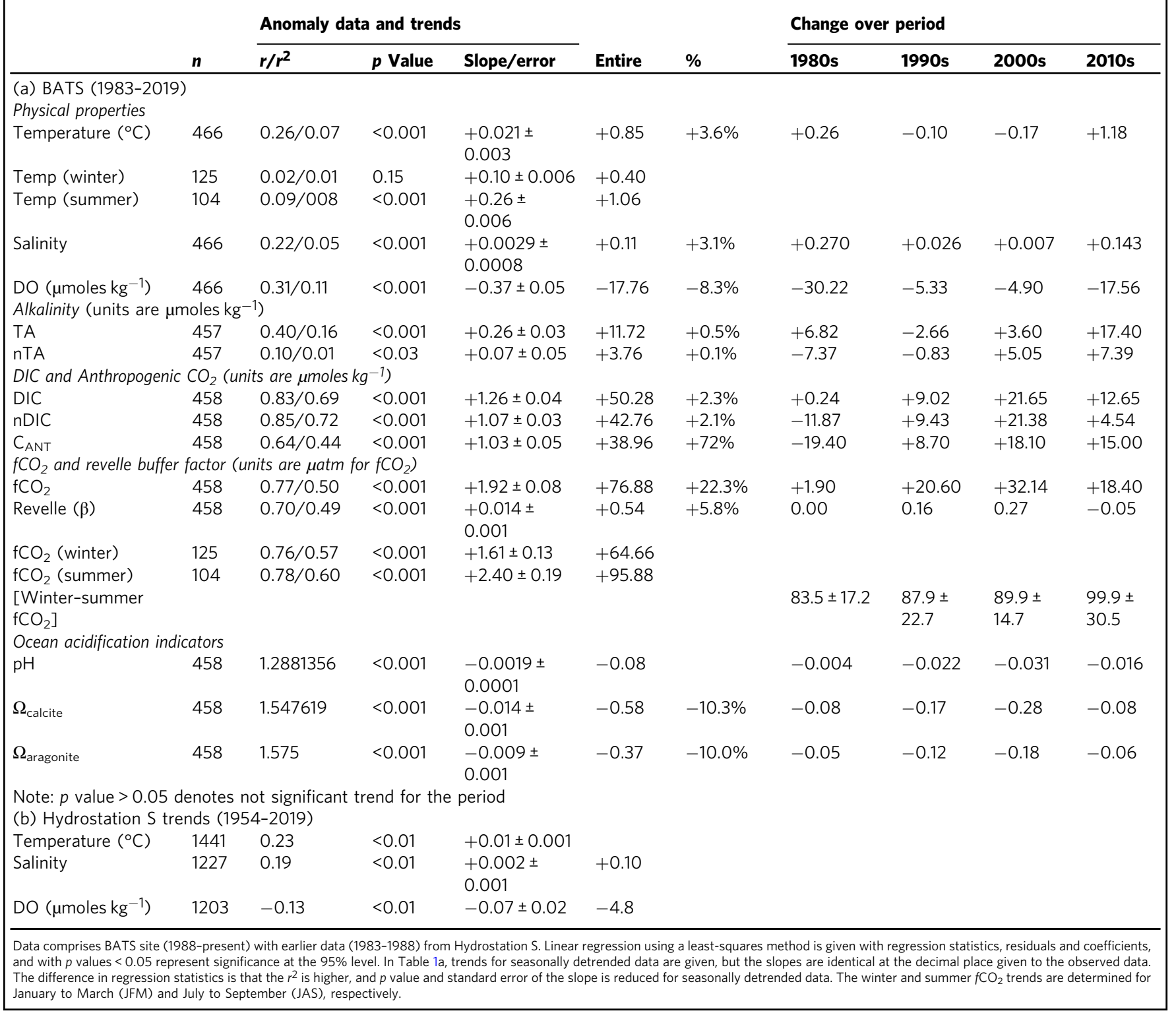

Surface ocean TA and DIC changes. The observations near Bermuda provide the longest record of seawater $\mathrm{CO}_{2}$-carbonate chemistry in the global open-ocean. Surface TA shows similar seasonal patterns to salinity, and a slight increase associated with salinity increases over time (Fig. 3c). However, salinity normalised alkalinity (nTA) shows marginally statistically significant changes over time (Table 1a; $p$-value of 0.03 ).

Surface DIC exhibits typical summer to wintertime seasonality of 30-40 $\mu$ moles $\mathrm{kg}^{-1}$, (Fig. $4 \mathrm{a}$, b; salinity normalised DIC also shows a similar pattern but with reduced seasonality ${ }^{13,36}$ ). Surface DIC and nDIC have significantly increased at rates of $1.26 \pm 0.04$ and $1.07 \pm 0.03 \mu$ moles $\mathrm{kg}^{-1}$ year $^{-1}$, respectively, over the past 40 years (Fig. 1d; Table 1a). The difference between DIC and nDIC trends indicate that salinity changes contributed about $20 \%$ of the changes in DIC.

Earlier studies at BATS ${ }^{36-40}$, elsewhere off Hawaii ${ }^{41}$ and the Canary Islands ${ }^{42}$, attribute the increase in DIC to the uptake of anthropogenic $\mathrm{CO}_{2}$ from the atmosphere ${ }^{7}$. Here, we use the TrOCA method to determine if the remaining $80 \%$ of DIC increase is due to anthropogenic $\mathrm{CO}_{2}$ uptake. The TrOCA $\operatorname{method}^{29}$ has limitations in use for anthropogenic $\mathrm{CO}_{2}$ quantification $^{43}$ but nevertheless, provides a useful tracer of ocean chemical changes when used at a fixed location. In the Sargasso Sea, TrOCA derived anthropogenic carbon concentration $\left(\mathrm{C}_{\mathrm{ANT}}\right)$ surface values exhibit seasonal ranges of $\sim 30-40$ $\mu$ moles $\mathrm{kg}^{-1}$ (Fig. 4c, d). Importantly, $\mathrm{C}_{\mathrm{ANT}}$ has increased by $\sim 38$ $\mu$ moles $\mathrm{kg}^{-1}(+72 \%)$ over the past 30 years, with anthropogenic $\mathrm{CO}_{2}$ concentration almost doubling in the upper ocean (Fig. 1d; Table 1a). The rate of increase of $\mathrm{C}_{\mathrm{ANT}}$ and nDIC are very similar $\left(1.03 \pm 0.05\right.$ vs. $1.07 \pm 0.03 \mu$ moles $\mathrm{kg}^{-1}$ year $^{-1}$; Table 1a) and indicative that ocean uptake of anthropogenic $\mathrm{CO}_{2}$ uptake has substantially changed ocean carbon chemistry over the past four decades at least.

Surface ocean $\mathrm{fCO}_{2}$ and Revelle factor changes. Surface seawater $\mathrm{fCO}_{2}$ also exhibits substantial seasonality with typical ranges of $\sim 40-60 \mu \mathrm{atm}$ (Figs. 2a and 4e, f). This variability reflects the underlying seasonality of temperature and DIC (similar trends 

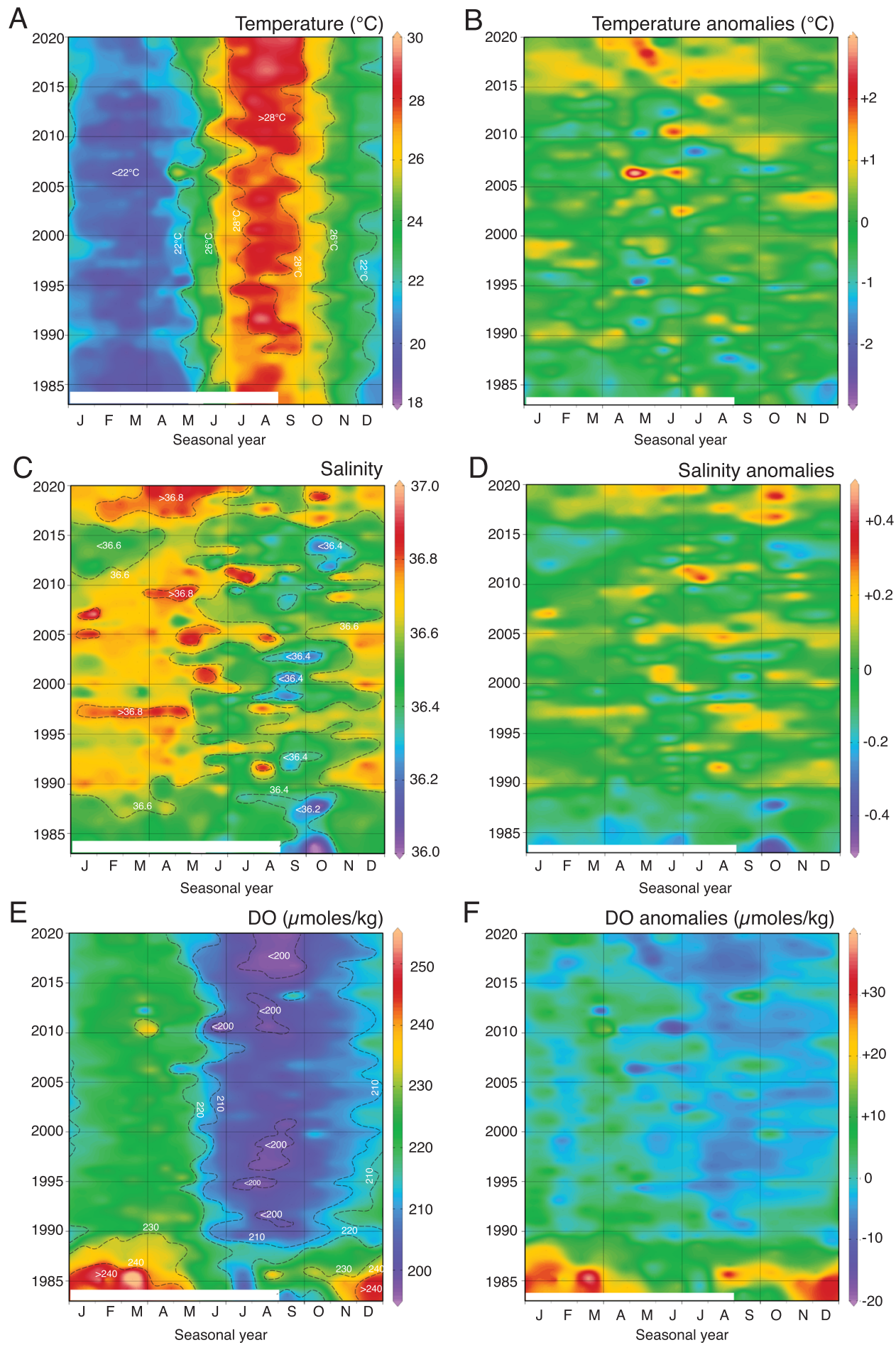

Fig. 3 Physical properties at BATS (1988-present) with earlier data (1983-1988) from Hydrostation S. a Surface temperature $\left({ }^{\circ} \mathrm{C}\right)$. b Surface temperature anomalies $\left({ }^{\circ} \mathrm{C}\right)$. c Surface salinity. d Surface salinity anomalies. e Surface dissolved oxygen DO $\left(\mu \mathrm{moles} \mathrm{kg}^{-1}\right.$ ). $\mathbf{f}$ Surface dissolved oxygen DO anomalies $\left(\mu\right.$ moles $\mathrm{kg}^{-1}$ ). Please note that the occasional high and low summertime DO events observed in the 2000s occur both at hydrostation $\mathrm{S}$ and BATS indicating that these features are "real" surface phenomena. Dashed lines for contours are included.

and patterns observed for $p \mathrm{CO}_{2}$, or partial pressure of $\mathrm{CO}_{2}$, with typically less than $1 \mu \mathrm{atm}$ difference between $f \mathrm{CO}_{2}$ and $p \mathrm{CO}_{2}$ ). In response to anthropogenic $\mathrm{CO}_{2}$ uptake by surface waters and an increase in DIC, surface seawater $f \mathrm{CO}_{2}$ exhibited significant gain over the 40 years with $f \mathrm{CO}_{2}$ anomalies increasing by $\sim 76 \mu \mathrm{atm}$ (Fig. 4f; Table 1a). The rate of change of $f \mathrm{CO}_{2}$ is $1.92 \pm 0.08 \mu \mathrm{atm}$ year $^{-1}$ (Table 1a), representing an increase of nearly $25 \%$ from 1980 to 2020 . The winter and summer $\mathrm{fCO}_{2}$ values in recent years are higher and outside the range of surface $\mathrm{fCO}_{2}$ seasonality observed in the 1980s.

The increasing trend in seawater $f \mathrm{CO}_{2}$ observed in the North Atlantic Ocean is similar to observed changes in atmospheric $\mathrm{fCO}_{2}{ }^{16,41}$, and, over shorter time-scales, similar trends in surface seawater $\mathrm{fCO}_{2}$ have been reported elsewhere ${ }^{41,42}$. The observation that surface and atmospheric $f \mathrm{CO}_{2}$ have tracked each other over time implies that the driving force for air-sea $\mathrm{CO}_{2}$ gas exchange 

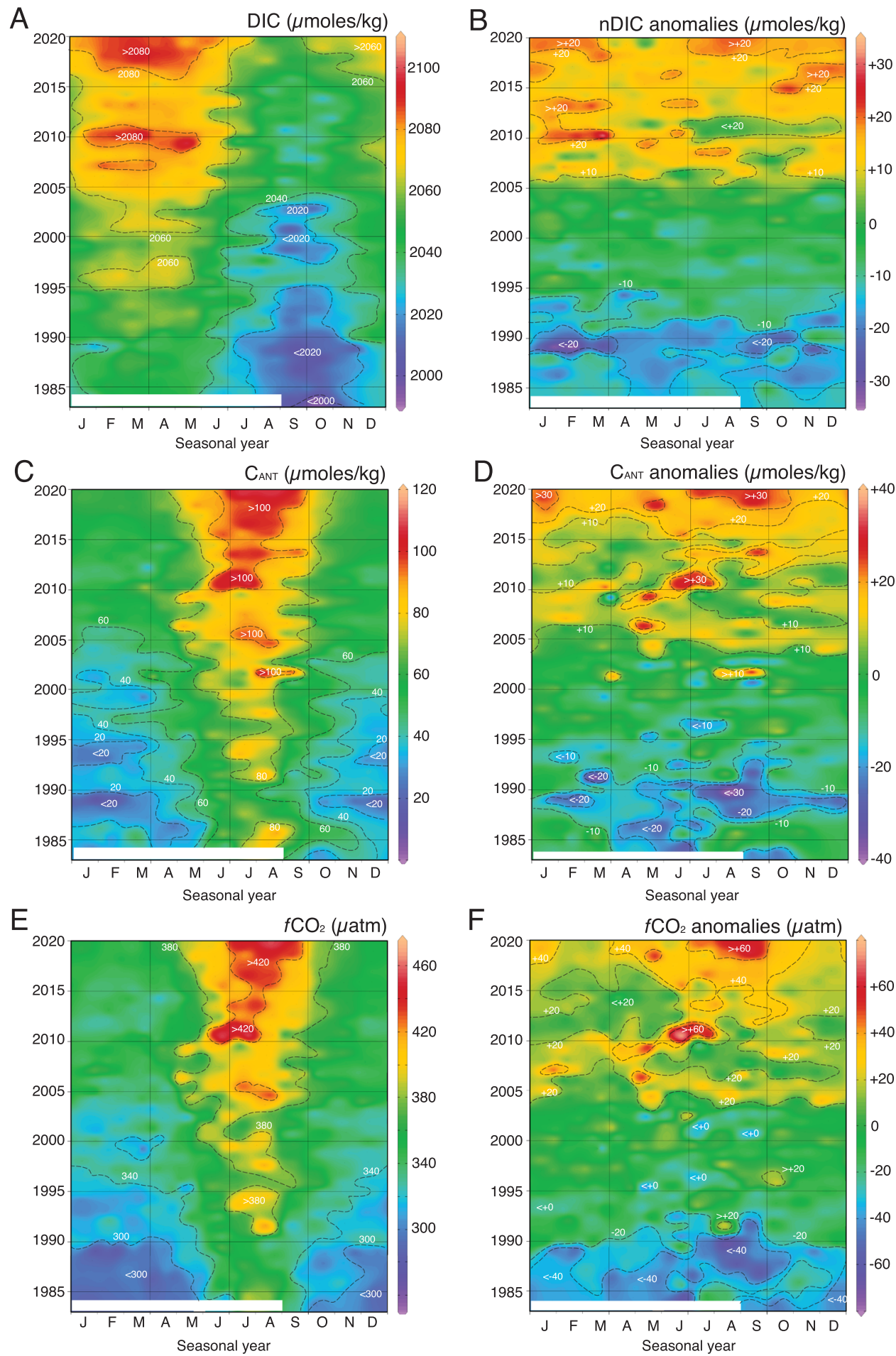

Fig. 4 Seawater $\mathrm{CO}_{2}$-carbonate properties at BATS (1988-present) with earlier data (1983-1988) from Hydrostation S. a Scatter plot of DIC ( $\mu$ moles $\mathrm{kg}^{-1}$ ). b Scatter plot of $\mathrm{nDIC}$ anomalies $\left(\mu\right.$ moles $\mathrm{kg}^{-1}$ ). c Scatter plot of $C_{\text {ANT }}\left(\mu\right.$ moles $\mathrm{kg}^{-1}$ ). $\mathbf{d}$ Scatter plot of of $C_{\text {ANT }}$ anomalies $\left(\mu\right.$ moles $\mathrm{kg}^{-1}$ ). e Surface $f \mathrm{CO}_{2}(\mu \mathrm{atm})$. $\mathbf{f}$ Surface $f \mathrm{CO}_{2}$ anomalies ( $\left.\mu \mathrm{atm}\right)$. Dashed lines for contours are included.

(i.e., $\Delta f \mathrm{CO}_{2}$; the $f \mathrm{CO}_{2}$ difference between atmosphere and seawater) and the ocean $\mathrm{CO}_{2}$ sink in the subtropical gyre has not changed significantly over the past 40 years. Earlier studies ${ }^{7,40}$ have concluded that the increases in $\mathrm{fCO}_{2}$ largely reflect uptake of anthropogenic $\mathrm{CO}_{2}$ and increasing DIC, with minor influences due to the small changes in temperature, salinity and alkalinity over time. As shown later, while surface and atmospheric $f \mathrm{CO}_{2}$ have tracked each other over the past 40 years, there is substantial decade-to-decade variation of seawater $\mathrm{fCO}_{2}$ increase (Table 1a; low of $+1.9 \mu$ atm per decade in the 1980 s to $+32 \mu$ atm per decade in the 2000s) and ocean $\mathrm{CO}_{2}$ uptake.

The Revelle factor $(\beta)$ reflects the underlying chemical state that can facilitate air-sea $\mathrm{CO}_{2}$ exchange ${ }^{44}$. In simple terms, the ocean's ability to absorb $\mathrm{CO}_{2}$ decreases with higher $\beta$ values ${ }^{12,45}$, and the chemical buffering capacity reduces. In the Sargasso Sea, the seasonality of $\beta$ is $\sim 0.4$, with wintertime values higher than summertime values. Lower $\beta$ conditions reflect the underlying capacity for seawater to absorb $\mathrm{CO}_{2}$, and yet the lowest $f \mathrm{CO}_{2}$ 
occurs in winter coincide with seasonally higher $\beta$ values. This finding demonstrates the influence of other factors on $\mathrm{fCO}_{2}$, such as temperature. An important observation is that the Revelle factor, $\beta$, is increasing over time $(\sim 0.54 \pm 0.04$; Fig. $2 b$, Table $1 \mathrm{a})$. These changes in ocean chemistry illustrate that the ocean capacity to absorb $\mathrm{CO}_{2}$ from the atmosphere is gradually declining ( $6 \%$ since 1980$)$, which provides additional future feedback for assessments of the quantitative fate of anthropogenic $\mathrm{CO}_{2}$ in the atmosphere and its transfer to the ocean.

Recently, Landschutzer et al. ${ }^{46}$ reported winter to summer $\mathrm{fCO}_{2}$ difference has increased from the 1980 s to the 2010 s by an average of $2.2 \mu \mathrm{atm}$ per decade with a rate of 1.5 and $3.8 \mu \mathrm{atm}$ per decade report for BATS and the Hawaii Ocean Time Series (but without details in the paper about how these rates were estimated). Such changes are attributed primarily to the longterm increase in the mean concentration of $\mathrm{CO}_{2}$ in the surface ocean, $\left[\mathrm{CO}_{2}\right]_{\mathrm{aq}}$, and increase in the Revelle factor due to the reaction of added $\mathrm{CO}_{2}$ with carbonate ion to reduce the capacity of the surface ocean $\mathrm{CO}_{2}$-carbonate system to buffer against changes. At the BATS-Hydrostation S site, it is difficult to capture the peak maximum (summer) and minimum (winter) $f \mathrm{CO}_{2}$ with monthly shipboard observations (i.e., the maximum and minimum $f \mathrm{CO}_{2}$ may occur between cruises). Nonetheless, the mean winter to summer $\mathrm{fCO}_{2}$ difference increases from the 1980 s to 2010 s (e.g., mean and standard error; 1980s, $83.6 \pm 17.2 \mu \mathrm{atm} ; 1990 \mathrm{~s}, 87.9 \pm 22.7 \mu \mathrm{atm} ; 2000 \mathrm{~s}$, $89.9 \pm 14.7 \mu \mathrm{atm} ; 2010 \mathrm{~s}, 99.2 \pm 11.4 \mu \mathrm{atm}$; Table 1a) contemporaneously with increasing $\left[\mathrm{CO}_{2}\right]_{\mathrm{aq}}$ and Revelle factor. The increase in mean winter to summer $f \mathrm{CO}_{2}$ difference is $4.1 \mu \mathrm{atm}$ per decade. Over the past nearly 40 years, the winter and summer $\mathrm{fCO}_{2}$ have increased at different rates of $1.62 \pm 0.13$ $\mu \mathrm{atm}$, and $2.40 \pm 0.19 \mu \mathrm{atm}$, respectively (Table $1 \mathrm{a}$; total $f \mathrm{CO}_{2}$ change of $\sim 65 \mu \mathrm{atm}$ and $\sim 96 \mu \mathrm{atm}$ in winter and summer). The winter and summer $f \mathrm{CO}_{2}$ difference has increased by $\sim 30 \mu \mathrm{atm}$ which is $\sim 7.9 \mu \mathrm{atm}$ per decade. The two approaches thus indicate increases of winter and summer $\mathrm{fCO}_{2}$ difference in the range of 4.1-7.9 $\mu \mathrm{atm}$ per decade, and three to five times the rates reported by Landschutzer et al. ${ }^{46}$ (their data covers the period 1988-2014). The divergent winter and summer $f \mathrm{CO}_{2}$ conditions appear associated with reduction in winter length and lower rate of warming (the season with water less than $22^{\circ} \mathrm{C}$ has reduced from $157.7 \pm 10.8$ days in the 1980 s to $124.7 \pm 24.7$ days in the 2010 s; $0.10^{\circ} \mathrm{C}$ decade $^{-1}$; Table $\left.1 \mathrm{a}\right)$, and increase in summer length and higher rate of warming (the season with water greater than $25^{\circ} \mathrm{C}$ has reduced from $121.0 \pm$ 23.4 days in the 1980 s to $140.3 \pm 11.3$ days in the 2010 s; $0.26^{\circ} \mathrm{C}$ decade $^{-1}$; Table 1a). The BATS-Hydrostation $\mathrm{S}$ winter to summer $f \mathrm{CO}_{2}$ difference also substantially increases by $\sim 10$ $\mu$ atm in the 2010s (due to summertime warming, Fig. 3a, and higher $f \mathrm{CO}_{2}$, Fig. $4 \mathrm{e}$ ).

OA indicators. The BATS and Hydrostation S time-series data allow direct detection of the signal of $\mathrm{OA}$ in surface waters of the North Atlantic Ocean. $\mathrm{CO}_{2}$ dissolved into seawater forms carbonic acid which rapidly dissociates into bicarbonate $\left[\mathrm{HCO}_{3}{ }^{-}\right]$ and in turn to carbonate $\left[\mathrm{CO}_{3}{ }^{2-}\right]$. Chemical equilibria reactions maintain mean contributions of $\left[\mathrm{HCO}_{3}^{-}\right],\left[\mathrm{CO}_{3}^{2-}\right]$, and $\left[\mathrm{CO}_{2}\right]_{\mathrm{aq}}$ to DIC at $\sim 88 \%, 11 \%$ and $1 \%$, respectively. $\mathrm{pH}$ and $\left[\mathrm{CO}_{3}{ }^{2-}\right]$ decrease as seawater absorbs $\mathrm{CO}_{2}$, a process termed $\mathrm{OA}^{15}$. OA is potentially impactful for those organisms that secrete $\mathrm{CaCO}_{3}$ skeletons, tests or shells and for marine ecosystems where calcification and $\mathrm{pH}$ controls on biogeochemical processes are important factors ${ }^{47}$. The typical $\mathrm{pH}$ range of surface waters in the 1980 s ranged from wintertime highs of $\sim 8.2$ to summertime lows of $\sim 8.08-8.10$ (Figs. $2 \mathrm{c}$ and $5 \mathrm{a}, \mathrm{b}$ ), with the ocean remaining

\begin{tabular}{|c|c|c|c|c|}
\hline & 1983 & 2019 & 2050 & 2100 \\
\hline DO & 228 & 212 & 199 & 177 \\
\hline DIC & 2031 & 2077 & 2115 & 2177 \\
\hline$C_{\text {ANT }}$ & 25 & 61 & 90 & 138 \\
\hline $\mathrm{fCO}_{2}$ & 310 & 381 & 439 & 535 \\
\hline Revelle $(\beta)$ & 8.89 & 9.39 & 9.8 & 10.48 \\
\hline $\mathrm{pH}$ & 8.138 & 8.062 & 8.005 & 7.91 \\
\hline$\Omega_{\text {calcite }}$ & 6.18 & 5.5 & 5.07 & 4.29 \\
\hline$\Omega_{\text {aragonite }}$ & 3.86 & 3.62 & 3.34 & 2.88 \\
\hline
\end{tabular}

Note: $\mathrm{DO}, \mathrm{DIC}$ and $\mathrm{C}$ are expressed units of $\mu$ moles $\mathrm{kg}^{-1}$, while $\mathrm{fCO}_{2}$ is expressed in units of $\mu$ atm. The Revelle $(\beta)$ factor, $\mathrm{pH}, \Omega_{\text {calcite }}$ and $\Omega_{\text {aragonite }}$ are dimensionless and do not have units.

mildly alkaline at present $(\sim 7.98-8.05)$. Concurrent with the changes in DIC, $\mathrm{C}_{\mathrm{ANT}}, f \mathrm{CO}_{2}$ and $\beta$ values, $\mathrm{pH}$ has also declined by approximately 0.07 from 1983 to 2020 (Fig. 2c; Table 1a).

The rate of $\mathrm{pH}$ change is $\sim 0.0019 \pm 0.0001$ year $^{-1}$, which is a more negative rate than previously reported ${ }^{7}$, and represents a $20 \%$ increase in hydrogen ion concentration since 1983). Both $\Omega_{\text {calcite }}$ and $\Omega_{\text {aragonite }}$ exhibit seasonal changes of $\sim 0.3-0.5$ (Fig. $5 c$, e), $\Omega_{\text {calcite }}$ and $\Omega_{\text {aragonite }}$ have decreased by 0.52 and 0.35 , the past 40 years (Figs. $2 \mathrm{~d}$, e and $5 \mathrm{~d}$, f; Table 1a) at rates of $0.014 \pm 0.001$ year $^{-1}$ and $0.009 \pm 0.001$ year $^{-1}$, respectively.

Present ocean carbon chemistry is now outside of 1980 s values. In forty years, seawater $\mathrm{CO}_{2}$-carbonate chemistry conditions are now altered beyond the seasonal chemical ranges observed in the 1980s (Table 2). For DIC and $\mathrm{fCO}_{2}$, the low winter values in 2020 were the high summer values in the $1980 \mathrm{~s}$. Similarly, for $\mathrm{pH}$, $\Omega_{\text {calcite }}$ and $\Omega_{\text {aragonite, the high summer values are at present the }}$ low winter values. The statistically significant time-scale of emergence for carbonate parameters in the Sargasso Sea is typically less than 10 years $^{48}$ (Table 2). The modification of seawater $\mathrm{CO}_{2}$-carbonate chemistry will continue with future anthropogenic $\mathrm{CO}_{2}$ emissions. Current chemical trends extended to 2050 indicate the following: Mean DO will be less than 200 $\mu$ moles $\mathrm{kg}^{-1}$, mean DIC $>2100 \mu$ moles kg-1, and $f \mathrm{CO}_{2}$ and $\mathrm{pH}$ approaching $450 \mu \mathrm{atm}$ and 8.000 , respectively (Table 2). If current rates of anthropogenic $\mathrm{CO}_{2}$ emissions continue until the end of the century, $\mathrm{fCO}_{2}$ will likely be at least $535 \mu \mathrm{atm}, \mathrm{C}_{\mathrm{ANT}}$ at $>138$ $\mu$ moles $\mathrm{kg}^{-1}$ (nearly five times the 1983 concentration) and $\mathrm{pH}$ and $\Omega_{\text {aragonite }}$ close to 7.9 and below 3 , respectively (Table 2 ). This end-of-century scenario is hypothetical given that $\mathrm{CO}_{2}$ emissions are likely to peak and decline with future climate policy instruments, with the result that ocean carbonate chemistry is not expected to reach such levels.

\section{Discussion}

Decadal variability of sargasso sea ocean carbon sinks. The Sargasso Sea observations off Bermuda reveal the substantial decadal variations. As with temperature and salinity, the 1990s and 2000s were periods of modest changes with low rates of oxygen decrease. In the decade of the 1980s and 2010s, the decline of oxygen was about $8 \%$ (Table $1 \mathrm{a}$ ), but with potentially different causes. In the $1980 \mathrm{~s}$, warming of $\sim 0.26^{\circ} \mathrm{C}$ contributed perhaps $5 \%$ to lower oxygen concentration. During the 2010 s, oxygen concentration decreased by $\sim 8 \%$. Approximately, $18 \%$ of that change was due to warming and the influence of temperature on oxygen solubility ${ }^{16}$. A combination of changes in gyre circulation, wind-driven ventilation and gas exchange may partly 

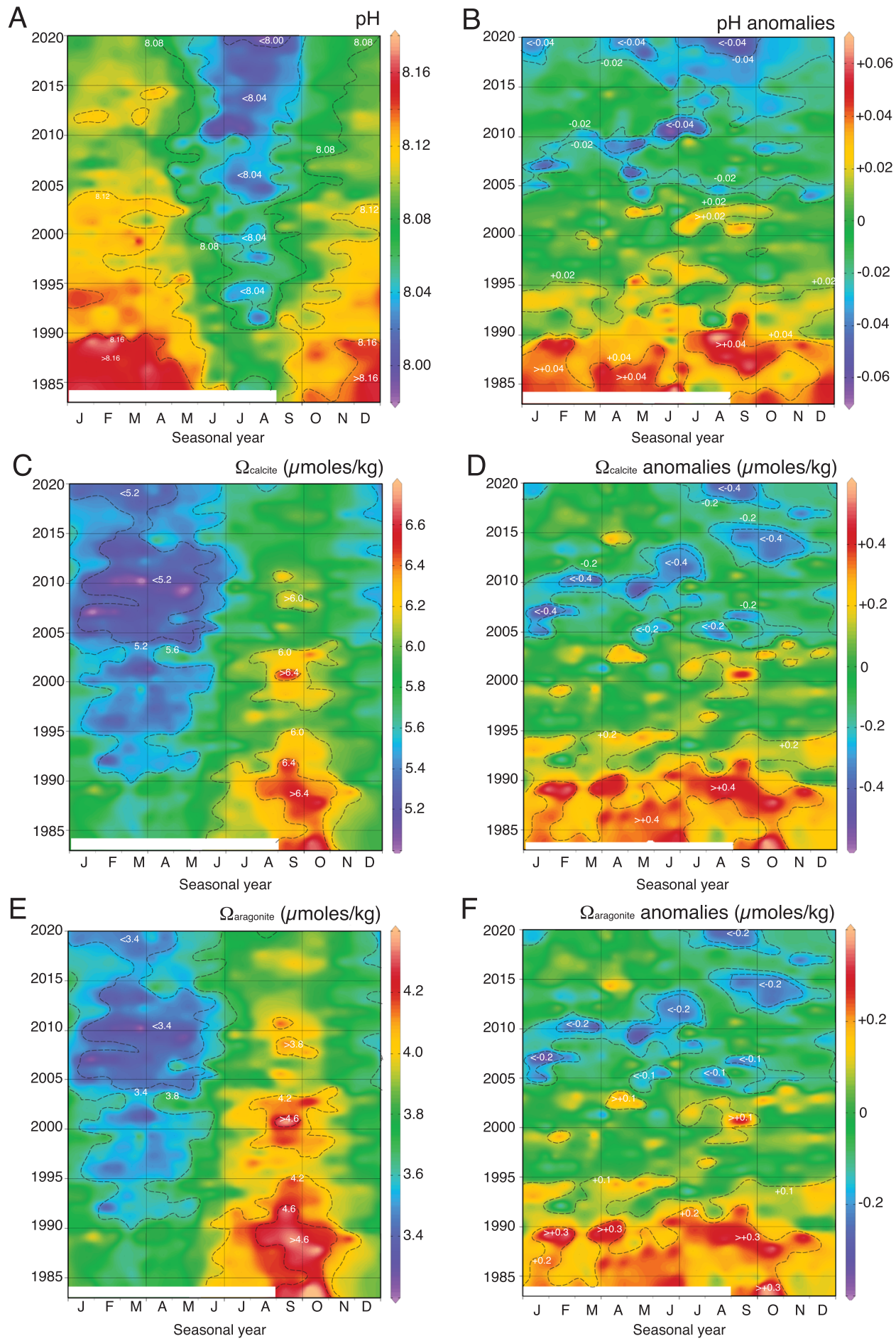

Fig. 5 Seawater $\mathrm{CO}_{2}$-carbonate properties at BATS (1988-present) with earlier data (1983-1988) from Hydrostation S. a Surface $\mathrm{pH}$. b Surface $\mathrm{pH}$ anomalies. c Surface $\Omega_{\text {calcite. }}$ d Surface $\Omega_{\text {calcite }}$ anomalies. e Surface $\Omega_{\text {aragonite. }}$ f Surface $\Omega_{\text {aragonite }}$ anomalies. Dashed lines for contours are included.

explain such decade to decade variation on DO loss. The slowdown of Atlantic Meridional Overturning Circulation remains unproven at present, and it is challenging to link loss of oxygen in the subtropical gyre to basin-scale changes. The underlying drivers for loss of oxygen in the subtropical gyre are the scope of future work.

An important additional finding from the BATS-Hydrostation $S$ time-series is that although long-term trends of DIC result from anthropogenic $\mathrm{CO}_{2}$ uptake, there is a substantial decade to decade variation in changes. In the 1980s; associated with salinification and an $8 \%$ DO decrease, both nDIC and nTA also declined by 11.8 and $7.3 \mu$ moles $\mathrm{kg}^{-1}$, respectively (Table 1a). Prior studies of nDIC and nTA show that both decrease meridionally by $15-30$ $\mu$ moles $\mathrm{kg}^{-1}$, from subpolar waters into the subtropical gyres of the Atlantic, Pacific and Indian Oceans ${ }^{49}$. The salinification event at the end of the 1980s may mark a transition in North Atlantic subtropical gyre circulation and wind-driven ventilation, and perhaps a change to water masses with a more "southern" subtropical gyre physical and biogeochemical character (i.e., warmer, higher salinity and lower oxygen contents). If we assume 
Table 3 Comparison of atmospheric $\mathrm{CO}_{2}$ increase, global ocean carbon sinks and Sargasso Sea carbon sink for recent decades.

\begin{tabular}{|c|c|c|c|c|c|}
\hline & & \multicolumn{4}{|c|}{ Change over period } \\
\hline & & 1980s & 1990s & 2000s & 2010s \\
\hline \multirow[t]{2}{*}{ Atmospheric $\mathrm{CO}_{2}$ increase } & [De Vries et al. $\left.{ }^{8}\right]$ & $\mathrm{n} / \mathrm{a}$ & Higher $^{8}$ & Lower $^{8}$ & $\mathrm{n} / \mathrm{a}$ \\
\hline & {$\left[\right.$ McKinley et al. $^{30}$ ] } & $\mathrm{n} / \mathrm{a}$ & Weak (4.4\% decade ${ }^{-1}$ ) & Strong (5.4\% decade $\left.{ }^{-1}\right)$ & $\mathrm{n} / \mathrm{a}$ \\
\hline \multirow[t]{2}{*}{ Global ocean carbon sinks } & [De Vries et al. $\left.{ }^{8}\right]$ & $\mathrm{n} / \mathrm{a}$ & Weak $(-8$ to $-16 \%)$ & Strong $(+35$ to $+43 \%)$ & $\mathrm{n} / \mathrm{a}$ \\
\hline & [McKinley et al. ${ }^{30}$ ] & $\mathrm{n} / \mathrm{a}$ & Weak ( -17 to $-28 \%)$ & Strong $(+24$ to $+69 \%)$ & $\mathrm{n} / \mathrm{a}$ \\
\hline \multirow[t]{4}{*}{ Sargasso Sea carbon sink } & [This study; $\left.\mathrm{C}_{\mathrm{ANT}}\right]$ & $\mathrm{n} / \mathrm{a}$ & Weak $(-16 \%)$ & Strong $(74 \%)$ & Strong (55\%) \\
\hline & {$\left[C_{\text {ANT }}\right.$ increase $]$} & $-1.94 \pm 1.23$ & $+0.87 \pm 0.50$ & $+1.81 \pm 0.53$ & $+1.50 \pm 0.58$ \\
\hline & {$\left[\mathrm{fCO}_{2}\right.$ increase $]$} & $+0.19 \pm 0.08$ & $+2.06 \pm 0.08$ & $+3.21 \pm 0.08$ & $+1.84 \pm 0.08$ \\
\hline & [Winter-summer $\left.\mathrm{fCO}_{2}\right]$ & $83.5 \pm 17.2$ & $87.9 \pm 22.7$ & $89.9 \pm 14.7$ & $99.9 \pm 30.5$ \\
\hline \multicolumn{6}{|c|}{$\begin{array}{l}\text { Note: the change is given in units of } \mu \text { moles } \mathrm{kg}^{-1} \text { year } \\
\text { to emissions is higher in the } 1990 \mathrm{~s} \text { compared to } \mathrm{fCO}_{2} \text { increase is } \mu \text { atm year }{ }^{-1} \text {. The winter-summer } f \mathrm{CO}_{2} \text { difference is given units of } \mu \text { atm. The accumulation of } \mathrm{CO}_{2} \text { in the atmosphere relative } \\
\text { In Table } 3 \text {, the designation of "weak" and "strong" global ocean uptake is taken from DeVries et al. }{ }^{8} \text {. The \% change in global ocean uptake is taken from DeVries et al. }{ }^{8} \text { and McKinley et al. }{ }^{30} \text {, and } \\
\text { represents the change in ocean sink between the beginning and end of the decade, and the range determined from the various approaches used in each of their studies. The change in } \mathrm{C}_{\mathrm{ANT}} \text { in the } \\
\text { anthropogenic } \mathrm{CO}_{2} \text { relative to the long-term increase of } 1.03 \pm 0.05 \mu \text { moles } \mathrm{kg}^{-1} \text {. Positive increases denoted in } \% \text { indicate that the } \mathrm{C}_{\mathrm{ANT}} \text { has increased at a higher rate relative to the long-term trend and } \\
\text { thus indicate increase ocean uptake of anthropogenic } \mathrm{CO}_{2} \text {. }\end{array}$} \\
\hline
\end{tabular}

an increase of DIC due to uptake of anthropogenic $\mathrm{CO}_{2}(\sim 9$ $\mu$ moles $\mathrm{kg}^{-1}$ ) for the decade of the 1980s in the Sargasso Sea, the nDIC content of a more "southern" water mass would likely have been $\sim 20 \mu$ moles $\mathrm{kg}^{-1}$ lower.

Since the 1990s, the three decades have exhibited different DIC, nDIC, TA and nTA changes (Table 3). The largest increase in nDIC occurred in the 2000s. The finding of such significant decade to decade variation in seawater $\mathrm{CO}_{2}$-carbonate chemistry has implications for determination of trends from shorter duration observations which likely have interannual to decadal change. Trend analysis of seawater $\mathrm{CO}_{2}$-carbonate chemistry, as with other ocean physical and biogeochemical properties, thus requires long-term data.

Recently, DeVries et al. ${ }^{8}$ and McKinley et al. ${ }^{30}$ reported substantial decadal variation in the global ocean carbon sink with climate variability a highly influential driver of ocean carbon uptake. In the 1990s, enhanced accumulation of $\mathrm{CO}_{2}$ in the atmosphere relative to $\mathrm{CO}_{2}$ emissions ${ }^{8}$ was accompanied by a period of reduced global ocean carbon uptake $(\sim-8$ to $-28 \% 8,30$ from beginning to end of the decade; Table 3 ). In contrast, in the 2000 s, the atmospheric $\mathrm{CO}_{2}$ growth rate slowed relative to higher anthropogenic $\mathrm{CO}_{2}$ emissions ${ }^{8}$ while the global ocean carbon sink increased ( +24 to $+69 \%$ from beginning to end of the decade; Table 3), with indications of a strengthening terrestrial carbon sink ${ }^{8}$. The Sargasso Sea $\mathrm{C}_{\mathrm{ANT}}$ data adds regional weight to these findings if we use $\mathrm{C}_{\mathrm{ANT}}$ changes as a proxy for ocean carbon uptake. In the $1990 \mathrm{~s}$, the rate of $\mathrm{C}_{\mathrm{ANT}}$ increase was lower by $16 \%$ (i.e., $+0.87 \pm 0.50 \mu$ moles $\mathrm{kg}^{-1}$ year $^{-1}$; Table 3 ), compared to the 1983-2020 change of $+1.03 \mu$ moles $\mathrm{kg}^{-1}$ year ${ }^{-1}$, indicative of lower anthropogenic $\mathrm{CO}_{2}$ accumulation (and ocean uptake) during the decade. In contrast, in the 2000s the rate of $\mathrm{C}_{\mathrm{ANT}}$ increase was higher by $74 \%$ (i.e., $+1.81 \pm 0.53 \mu$ moles $\mathrm{kg}^{-1}$ year ${ }^{-1}$; Table 3) were indicative of doubling of $\mathrm{CO}_{2}$ accumulation (and ocean uptake) during the decade. Higher $\mathrm{C}_{\mathrm{ANT}}$ accumulation in the Sargasso Sea (i.e., $+1.50 \pm 0.58 \mu$ moles $^{-1}$ year $^{-1}$; Table 3) may reflect the continuation of higher ocean carbon uptake in the 2010s from the 2000s.

The decade to decade variability in $\mathrm{C}_{\mathrm{ANT}}$ also covaries with rates of $f \mathrm{CO}_{2}$ change and winter-summer $f \mathrm{CO}_{2}$ difference. For example, the highest $\mathrm{C}_{\mathrm{ANT}}$ increase occurs in the 2000s along with higher $f \mathrm{CO}_{2}$ increases and winter-summer $f \mathrm{CO}_{2}$ difference (Table 3). This finding adds regional evidence to the study of Landschützer et al. $^{46}$ that winter-summer $\mathrm{fCO}_{2}$ difference is increases. Following the methods of Landschutzer et al. ${ }^{46}$ that derive the thermal and non-thermal components that drive the differential winter and summer changes, the winter and summer DIC changes at BATS have a near identical influence on $\mathrm{CCO}_{2}$. The thermal changes have a one-third and two thirds influence on $f \mathrm{CO}_{2}$ in winter and summer, respectively. The non-thermal changes of $f \mathrm{CO}_{2}$ are driven by an increase in nTA $(0.29 \mu$ moles $\mathrm{kg}^{-1}$ year ${ }^{-1}$ ) in winter and decrease in nTA in summer $\left(\sim 0.13 \mu\right.$ moles $\mathrm{kg}^{-1}$ year $\left.^{-1}\right)$. At BATS, the differential changes in winter and summer temperature, and increase/decrease in alkalinity drive the 4-8 $\mu \mathrm{atm}$ per decade increase in winter-summer $\mathrm{fCO}_{2}$ difference over the past forty years. In contrast, Landschutzer et al. ${ }^{46}$ reported a change of $1.5 \mu \mathrm{atm}$ per decade, but critically, ignored the effect of alkalinity changes in their analysis. Here, we demonstrate that observed changes in alkalinity do make a substantial difference for evaluating changes in winter-summer $\mathrm{fCO}_{2}$ difference over time and the need to incorporate TA for global syntheses ${ }^{46}$.

Nearly, 40 years of data at BATS-hydrostation S also indicate that the ocean is not uniformly changing over time, and there is a substantial decade to decade variation in $\mathrm{CO}_{2}$-carbonate chemistry. And that the ocean carbon sink is not stable over recent time and varies from decade to decade. If the coupling of atmospheric $\mathrm{CO}_{2}$ accumulation, ocean carbon sink and climate variability 8,30 is proven, the Sargasso Sea appears to act in concert with global decade to decade changes in ocean carbon sinks.

In summary, these data reveal recent warming in the last decade, associated with salinification and substantial deoxygenation. These physical changes were accompanied with significant increases of DIC and $f \mathrm{CO}_{2}$, and $20-40 \%$ decreases in $\mathrm{pH}, \Omega_{\text {calcite }}$ and $\Omega_{\text {aragonite, respectively, since the } 1980 \text { s. Apparent reduced }}$ ocean carbon uptake in the decades of the 1990s and higher $\mathrm{CO}_{2}$ uptake 2000s/2010s in the Sargasso Sea agree with the findings of decadal variability in "weaker"/"stronger" global ocean carbon uptake 8,30 and points to reduced ocean uptake in the Sargasso Sea in the 2010s. Such data on ocean physics and chemistry provide critically needed and unparalleled observational tests of coupled ocean-atmosphere models and future refinement of drivers for a model-data decade to decade assessment of the global carbon cycle.

\section{Methods}

Sampling methods. Ocean sampling at hydrostation S and BATS started in 1954 and 1988, respectively. Hydrostation S began with the pioneering efforts of Hank Stommel (Woods Hole Oceanographic Institution) and colleagues ${ }^{50}$ at a site approximately $26 \mathrm{~km}$ southeast of Bermuda $\left(32^{\circ} 10^{\prime} \mathrm{N}, 64^{\circ} 30^{\prime} \mathrm{W}\right.$, Fig. 1$)$. The first 
water-column sampling occurred on the 7th June 1954 from the $61^{\prime}$ R.V. Panularis with more than 1381 cruises conducted up to the present time from the R.V. Panularis II (1967-1983), R.V. Weatherbird (1983-1989); R.V. Weatherbird II (1989-2006) and R.V. Atlantic Explorer (2006-present).

Since the arrival of the R.V. Weatherbird, Hydrostation $\mathrm{S}$ has been occupied at near biweekly intervals, with multiple CTD-hydrocasts through the water-column to $\sim 2600 \mathrm{~m}$, and to $4500 \mathrm{~m}$ at BATS (more than 450 cruises to the site). Nansen bottles were used for water sampling at first, then $5 \mathrm{~L}$ Niskin samplers until October 1988. Thereafter sampling has been conducted with a Seabird 9/11 CTD equipped with $12 \mathrm{~L}$ Niskin and Ocean Test Equipment (OTE) samplers.

Water sampling, temperature and CTD measurements. The sampling format has remained substantially consistent for the past 65 years, but with the introduction of CTD-hydrocast sampling in October 1988. From 1954 to 1988, reversing mercury thermometers were used for measurements of temperature until replaced by CTD measurements using a Sea-Bird 9/11 system. Bottle samples before 2012 were taken down to $2600 \mathrm{~m}$ at hydrostation S. Since the addition of reliable altimeters to the CTD package, sampling was extended to full ocean depth at both the hydrostation S $(\sim 3400 \mathrm{~m})$ and BATS $(\sim 4500 \mathrm{~m})$ sites. Numerous sensor configurations have been used on the CTD package (e.g., dual temperature, dual conductivity, dual DO sensors, transmissometer, fluorometer, PAR and altimeter). In contrast, the CTD sampling system has predominately been a Seabird 24-place rosette using $12 \mathrm{~L}$ Ocean Test bottles. Before profiling, the CTD is allowed to stabilise at $10 \mathrm{~m}$ and once stable, the CTD returns to the surface to start the profile with typical descent rates of $0.5-1.0 \mathrm{~m} \mathrm{~s}^{-1}$, depending on weather conditions. Water samples are collected on the upcast, whereby the OTE bottles are closed at the target depth after a waiting period of $45 \mathrm{~s}$. The CTD is held at the target depth for another $10 \mathrm{~s}$ to allow the SBE35-RT sensor to take an $8 \mathrm{~s}$ average. The CTD continues with the upcast at an ascent rate of $0.7-1.0 \mathrm{~m} \mathrm{~s}^{-1}$. Temperature, conductivity and DO sensors are routinely returned to SeaBird every 6-9 months for routine calibration. The differences between primary and secondary temperature sensors in the deep ocean at BATS $(>3000 \mathrm{~m})$ were $0.002-0.006^{\circ} \mathrm{C}$ regardless of time since most recent factory calibration.

Determination of salinity. Salinity samples are typically taken from the OTE bottles at all depths. These samples are collected immediately following DO and $\mathrm{CO}_{2}$ sampling. Samples are taken in $125-250 \mathrm{ml}$ borosilicate glass bottles (Ocean Scientific, UK) that use plastic thimbles to form a better seal. The sample remaining from the previous use is left in the bottles between cruises to prevent salt crystal buildup due to evaporation. When drawing a new sample, the old sample is first discarded over the sampling spigot, and the bottle is rinsed three times with water from the new sample. The bottle is then filled to the shoulder with the sample, and the thimble inserted into the container. The neck of the bottle and the inside of the cap are dried, then the thimble is inserted, and the cap is replaced and firmly tightened. These samples are stored in a temperature-controlled laboratory for later analysis (typically within 1-2 weeks of their collection).

Salinity measurements have been made with a Guildline salinometer at BIOS from 1981 to present (calibrated with IAPSO standard water ${ }^{51}$ ) for both BATS and Hydrostation S samples. At present, samples for salinity are analysed on a Guildline Autosal 8400B laboratory salinometer using the manufacturer's recommended techniques. All readings (10 s average) are taken using the Ocean Scientific interface box and PC software. The salinometer drift during and between successive runs tends to be zero (room temperature carefully controlled and monitored). Bottle salinities are used to calibrate the profiling CTD SBE-04 sensors, and additionally, they are also compared with the downcast CTD profiles to search for possible outliers. Deep-water samples $(>2000 \mathrm{~m})$ are replicated for precision estimates (typically $<0.002$ salinity units).

Determination of DO. Early samples for DO were analysed by manual endpoint detection (1954-1988) though more recently, automated titration systems have been used (1988-present). On each hydrostation S and BATS cruise, the first samples from the rosette are taken for DO, immediately following the opening of the valve on the OTE bottle and confirmation that the OTE bottle has not leaked. The sample flasks used for this measurement are Pyrex iodine determination flasks of $140 \mathrm{ml}$ nominal capacity with ground glass barrel stoppers. The precise volume of each stopper/bottle pair is determined gravimetrically.

Seawater is carefully sampled to avoid the introduction of air bubbles with a minimum of five bottle volumes overflow. The samples are then immediately fixed with $1 \mathrm{ml}$ of manganous chloride and $1 \mathrm{ml}$ of sodium iodide/sodium hydroxide solution. With the stopper in place, and after vigorously shaking, the necks of the flasks are sealed with surface seawater. The samples are stored upright in the dark at $21-24^{\circ} \mathrm{C}$. The temperature of the water from the OTE bottle is measured to allow the conversion to units of mass.

The samples are analysed after $6-8 \mathrm{~h}$, based on the method proposed by Winkler (1888; modified by Strickland and Parsons $1968^{52}$ ). For this analysis, BIOS/BATS currently uses an automated temperature-controlled titration system (developed by SIO) using an ultra-violet light endpoint detection system with a
Metrohm 665 Dosimat burette for precise delivery of the sodium thiosulfate $(0.18$ M: reagent grade).

Before running the samples, the precise concentration of the thiosulfate and the chemical blanks are determined. Typically, six to eight standards are run for determination of a mean value. Blanks are prepared in the same manner as the standards. However, they are based on the $1 \mathrm{ml}$ standard addition of $\mathrm{KIO}_{3}$. The samples are run following the sodium thiosulphate normality determination. The water in the neck of the sample is carefully removed, taking care to avoid disturbing the precipitate. The stopper is then removed, and $1 \mathrm{ml}$ of $50 \%$ sulphuric acid added slowly, then a stir bar, and the sample titrated immediately. A 30\% triplication is performed for estimates of precision (typically $<0.4 \mu$ moles $\mathrm{kg}^{-1} ; 0.1 \%$ ).

Determination of DIC and TA. The description of seawater $\mathrm{CO}_{2}$-carbonate chemistry used in this paper follows long-established knowledge of the marine carbon cycle $e^{53-55}$. In this paper, DIC and TA were directly determined, and the chemical description of DIC is as follows ${ }^{53,54}$ :

$\mathrm{DIC}=\left[\mathrm{CO}_{2}{ }^{*}\right]+\left[\mathrm{HCO}_{3}{ }^{-}\right]+\left[\mathrm{CO}_{3}{ }^{2-}\right]$ [equation $\left.\mathrm{S} 1\right]$

The term $\left[\mathrm{CO}_{2}{ }^{*}\right]$ denotes the summed concentration of dissolved $\mathrm{H}_{2} \mathrm{CO}_{3}$ and $\mathrm{CO}_{2}$. The chemical description of alkalinity of seawater (TA) is defined ${ }^{53,54}$ as: $\mathrm{TA}=\left[\mathrm{HCO}_{3}{ }^{-}\right]+2\left[\mathrm{CO}_{3}{ }^{2-}\right]+\left[\mathrm{B}(\mathrm{OH})_{4}^{-}\right]+\left[\mathrm{OH}^{-}\right]+\left[\mathrm{HPO}_{4}{ }^{2-}\right]+2\left[\mathrm{PO}_{4}{ }^{3-}\right]$ $+\left[\mathrm{SiO}(\mathrm{OH})_{3}{ }^{-}\right]+\left[\mathrm{HS}^{-}\right]+\left[\mathrm{NH}_{3}\right]+$ minor species $-\left[\mathrm{H}^{+}\right]-\left[\mathrm{HSO}_{4}{ }^{-}\right]-[\mathrm{HF}]-$ $\left[\mathrm{H}_{3} \mathrm{PO}_{4}\right]-$ minor species [equation $\mathrm{S} 2$ ].

In this second chemical definition, the summed concentrations of $\left[\mathrm{HCO}_{3}{ }^{-}\right]+2$ $\left[\mathrm{CO}_{3}{ }^{2-}\right]+\left[\mathrm{B}(\mathrm{OH})_{4}{ }^{-}\right]$represent the major chemical components of TA and the proton/charge balance of seawater. Other chemical contributors to alkalinity are typically considered minor constituents in seawater ${ }^{54-56}$. Given DIC and TA are both expressed as $\mu$ moles $\mathrm{kg}^{-1}$ following long-established guidelines (Dickson et al., $2007^{54}$ and references therein).

Initially, at hydrostation S, samples for DIC and TA were collected into 11 Pyrex bottles with a change to $500 \mathrm{ml}$ bottles in the early 1990s, poisoned with $\mathrm{Hg}_{2} \mathrm{Cl}$, sealed with ground glass stoppers and then shipped to Scripps Institution of Oceanography (SIO) for analysis ${ }^{56,57}$ (1983-1988). Storage time for samples before analysis ranged from a few months to several years. Similar sampling protocols were established at BIOS for sampling at the BATS ${ }^{36,58,59}$, but in the early 2000 s, smaller Pyrex bottles $(350 \mathrm{ml}$ ) were used. Samples for DIC and TA have been typically analysed within a few months of collection at BIOS since 1988.

The sampling frequency of the combined dataset from hydrostation $S$ and BATS was not uniform in time. In the 1980s, samples were collected 9-12 times a year, while since 1992 , sampling increased to $14-15$ times a year 7,40 . The increase in sampling since the middle 1990s was due to supplemental BATS bloom cruises (1-4 in number) conducted during the January to April period in addition to BATS core cruises. The increase in sampling frequency over time weights the time-series to springtime when determining non-seasonally aliased trend $d^{7,40}$.

Potentiometric titration methods were also used for determination of TA at $\mathrm{BIOS}^{58}$. At the beginning of the 1990s, a manual alkalinity titrator was used for determination of TA at BIOS. This was replaced by an automated VINDTA 2S (Versatile Instrument for the Determination of Titration Alkalinity) in the early $2000 s^{40}$. For both manual and automated TA systems, 15-20 titration points past the carbonic acid endpoint were determined for each sample, with TA computed from these titration data using nonlinear least-squares methods ${ }^{54}$. Surface samples of Sargasso Sea water were also analysed each day before sample analyses, and certified reference materials (CRMs) were used routinely to calibrate the TA measurements.

At BIOS, DIC was determined using coulometric methods with a SOMMA system $7,40,54$. During the first 2 years of sampling, DIC samples were analysed at WHOI (e.g., BATS cruise 1-21), and subsequently at BIOS. DIC measurements were calibrated with known volumes of pure $\mathrm{CO}_{2}$ gas while $\mathrm{CRM}^{3}{ }^{5}$ were routinely analysed each day of analysis from 1991. Hydrostation S samples were analysed for DIC at SIO from 1983 to 1988 using manometric methods ${ }^{56}$. Potentiometric titration methods were used for determination of $\mathrm{TA}^{56}$ at $\mathrm{SIO}$, and after that at BIOS. No significant bias has been noted between these earlier methods (also analysed by A.G. Dickson to present) ${ }^{40}$. Analytical precision for DIC and TA at BIOS was typically $<0.03 \%$ and $<0.05 \%$, respectively for within the bottle and between bottle replicate analyses of more than 5,000 samples $^{40}$. Analytical accuracy for both DIC and TA using CRM analyses is better than $0.1 \%$.

Seawater $\mathrm{CO}_{2}$-carbonate chemistry computations and errors. The suite of seawater $\mathrm{CO}_{2}$-carbonate parameters (i.e., $\left[\mathrm{CO}_{2}\right],\left[\mathrm{H}_{2} \mathrm{CO}_{3}\right],\left[\mathrm{HCO}_{3}{ }^{-}\right],\left[\mathrm{CO}_{3}{ }^{2-}\right]$, $\left[\mathrm{H}^{+}\right]$) for each sample can be determined from the measurement of any two parameters (i.e., DIC, TA, $f \mathrm{CO}_{2}, p \mathrm{CO}_{2}$ and $\mathrm{pH}$ ), along with temperature and salinity ${ }^{53,54,55}$ Seawater $f \mathrm{CO}_{2}$ (fugacity of $\mathrm{CO}_{2}$ ) is used here rather than the partial pressure of $\mathrm{CO}_{2}$ (i.e., $p \mathrm{CO}_{2}$; note that this parameter was also computed in data files), and with units of $\mu$ atm. $\mathrm{pH}, \Omega_{\text {calcite, c a }}$ and $\Omega_{\text {aragonite }}$ in seawater are dimensionless and $\mathrm{pH}$ expressed on the total scale ${ }^{54}$. All parameters are computed at in situ temperature and salinity.

Here, seawater $f \mathrm{CO}_{2}, \mathrm{pH},\left[\mathrm{CO}_{3}{ }^{2-}\right]$, mineral saturation states for $\Omega_{\text {calcite }}$ and $\Omega_{\text {aragonite }}$, the Revelle factor $(\beta)$ were computed from DIC, TA, temperature and salinity data using the programme $\mathrm{CO}_{2} \mathrm{calc}^{60}$. Carbonic acid dissociation constants (i.e., $\mathrm{pK}_{1}$ and $\left.\mathrm{pK}_{2}\right)^{61}$, as refit by Dickson and Millero $(1987)^{62}$ were used for the computation, as well as dissociation constants for $\mathrm{KHSO}_{4}{ }^{-63}$, borate ${ }^{64}$. 
The computation error estimates for calculation of $p \mathrm{CO}_{2}, \mathrm{pH}, \Omega_{\text {calcite }}$ and $\Omega_{\text {aragonite }}$ were undertaken using standard procedures for the propagation of uncertainty ${ }^{54}$. Given the analytical uncertainty of the two seawater carbonate chemistry parameters (i.e., DIC and TA; $\pm 1 \mu$ moles $\mathrm{kg}^{-1}$ ) from replicate measurements of CRM's, the error of the computation is estimated at $3 \mu \mathrm{atm}, 0.003,0.018$, and 0.012 , for $p \mathrm{CO}_{2}, \mathrm{pH}$, and $\Omega_{\text {calcite }}$ and $\Omega_{\text {aragonite }}$ for surface waters, respectively ${ }^{65}$.

Use of the tracer TrOCA. TrOCA and TA is a method first proposed by Touratier and Goyet (2004a, b) ${ }^{66,67}$, and updated by Touratier et al. $(2007)^{29}$ to quantify anthropogenic carbon (i.e., $\mathrm{C}_{\mathrm{ANT}}$ ) in seawater. The quasi-conservative tracer, TrOCA in water masses accounts for changes in carbonate chemistry due to biological influences (e.g., remineralization of organic matter) and abiotic processes (e.g., dissolution of $\mathrm{CaCO}_{3}$ ), and as such, is also useful for following ocean chemistry changes in the surface ocean. Here, the formulation proposed by Touratier et al. $\left(2007^{29}\right.$; their equation 11$)$ is used as a water tracer:

$\mathrm{C}_{\mathrm{ANT}}=\left(\left[\mathrm{O}_{2}\right]+1.279 \times(\mathrm{DIC}-\mathrm{TA} / 2)-\mathrm{EXP}\left(7.511-1.087 \times 10^{-2} \times \Phi-\right.\right.$ $\left.\left.\left.7.81 \times 10^{5} / \mathrm{TA}^{2}\right)\right) / 1.279\right)$ ) [equation S3]

$\Phi$ is the potential temperature. The uncertainty of the estimate is $\sim 6 \mu$ moles $\mathrm{kg}^{-1}$ (29). The $\mathrm{C}_{\mathrm{ANT}}$ estimates determined using the TrOCA method for the mixed layer are modified by euphotic zone biological activity and air-sea gas exchange ${ }^{23}$, but, over time, provide additional evidence for changes in ocean chemistry.

Trend analyses. Trend analyses were conducted of the time-series of surface temperature and salinity, seawater carbonate chemistry (DIC, TA, $p \mathrm{CO}_{2}$ and Revelle factor) and OA indicators ( $\mathrm{pH},\left[\mathrm{CO}_{3}{ }^{2-}\right], \Omega_{\text {calcite }}$ and $\Omega_{\text {aragonite }}$ ). Here, trend analysis of salinity normalised DIC (nDIC), and TA (nTA) data were also made to account for local evaporation and precipitation changes. These data were normalised to salinity of 36.6 , as this represents the mean salinity observed at the BATS site ${ }^{37,40}$. Trend analysis was performed with observed data, and seasonally detrended data is given in Table 1) Statistics generated from least-squares regression approaches were slope, coefficients, error, multiple $r, r^{2}, p$ value and $n$. Trends with $p$ values greater than 0.01 were deemed statistically not significant at the $99 \%$ confidence level.

Trend analysis for the period from 1983 to 2020 , and for each decade (i.e., the 1980s, 1990s, 2000s, 2010s) was determined using linear regression methods with physical and biogeochemical data are the dependent variable and time as independent, and $p$ values $<0.05$ used to determine statistical significance of trend. Trend analyses with observed data exhibit seasonal aliasing due to sampling weighting to spring conditions ${ }^{12,13}$. To account for seasonal weighting, the data were also seasonally detrended ${ }^{68}$. Seasonal detrending of the BATS/Hydrostation S data was accomplished by binning data into the appropriate month, with mean values calculated from two or more cruises conducted within a representative month each year. This provides a uniform time step of approximately 1 month (i.e., 365 or 366 days/12) throughout the time-series, thereby removing any potential seasonal weighting especially to springtime conditions. Secondly, a mean and standard deviation is then determined each month for the 1983-2020, and anomalies computed from monthly data minus mean values. Trends and regression statistics anomaly data determined from seasonally detrended data are given in Table 1. Removing any potentially seasonal weighting allowed trend analysis of data that had any non-temporal uniformity reduced as much as possible.

BATS and Hydrostation S data. The BATS and Hydrostation S sites have been sampled on a monthly and twice-monthly basis, respectively, since October 1988. The data is publicly and permanently available at http://bats.bios.edu/data/ with a transition to BCO-DMO (Biological and Chemical Oceanography Data Management Office; Woods Hole, USA). The data used are primarily fully processed CTD profiles and bottle data with both dataset available to the end of 2019. The surface data is also available as Supplemental Data accompanying this paper. Information regarding CTD processing and QC routines are detailed at http://bats.bios.edu/wpcontent/uploads/2017/07/report_methods.pdf.

\section{Data availability}

The BATS data used in this paper are available as a supplemental data file accompanying the paper. All BATS and Hydrostation S bottle and CTD data are freely available up to the end of 2019 at http://www.bios.edu/research/projects/bats/. Information regarding CTD processing and QC routines are detailed at http://bats.bios.edu/wp-content/ uploads/2017/07/report_methods.pdf. The CTD and bottle data used here have been separately uploaded to BCO-DMO (Biological \&Chemical Oceanography Data Management Office) data repository (https://www.bco-dmo.org/) and will be freely available with a doi to CTD and bottle data. Please not that observed data are given (e.g., temperature, salinity, dissolved oxygen, DIC and TA) but not calculated parameters in accordance with BCO-DMO policies.

Received: 2 March 2020; Accepted: 18 September 2020; Published online: 16 October 2020

\section{References}

1. Menzel, D. W. \& Ryther, J. H. The annual cycle of primary production in the Sargasso Sea off Bermuda. Deep Sea Res. 6, 351-367 (1960).

2. Phillips, H. E. \& Joyce, T. M. Bermuda's tale of two time series: Hydrostation 'S' and BATS. J. Phys. Oceanogr. 37, 554-571 (2007).

3. Michaels, A. F. \& Knap, A. H. Overview of the U.S. JGOFs Bermuda Atlantic Time-series study and the hydrostation S program. Deep Sea Res. II 43, 157-198 (1996).

4. Steinberg, D. K. et al. Overview of the US JGOFS Bermuda Atlantic Time-series Study (BATS): a decade-scale look at ocean biology and biogeochemistry. Deep Sea Res. II 48, 1405-1447 (2001).

5. Gruber, N., Bates, N. R. \& Keeling, C. D. Interannual variability in the North Atlantic Ocean carbon sink. Science 298, 2374-2378, (2002).

6. Lomas, M. W. et al. Two decades and counting: 24 years of sustained open ocean biogeochemical measurements in the Sargasso Sea. Deep Sea Res. II 93, 16-32 (2013).

7. Bates, N. R. et al. Changing ocean chemistry: a time-series view of ocean uptake of anthropogenic $\mathrm{CO}_{2}$ and ocean acidification. Oceanography 27, 121-141 (2014).

8. DeVries, T. et al. Decadal trends in the ocean carbon sink. Proc. Natl Acad. Sci. USA 116, 11646-11651 (2019).

9. Le Quéré, C. et al. (2017). Global Carbon Budget 2017. Earth Syst. Sci. Data https://doi.org/10.5194/essd-2017-123 (2017).

10. Friedlingstein, P. et al. Global carbon budget, 2019. Earth Syst. Sci. Data 11, 1783-1838 (2019).

11. Takahashi, T. et al. Climatological mean and decadal change in surface ocean $\mathrm{pCO}_{2}$, and net sea-air $\mathrm{CO}_{2}$ flux over the global oceans. Deep Sea Res. II 56, 554-577 (2009).

12. Sabine, C. L. et al. The oceanic sink for anthropogenic $\mathrm{CO}_{2}$. Science $\mathbf{3 0 5}$, 367-371 (2004).

13. Khatiwala, S. et al. Global ocean storage of anthropogenic carbon. Biogeosciences 10, 2169-2191 (2013).

14. Gruber, N. et al. The oceanic sink for anthropogenic $\mathrm{CO}_{2}$ from 1994 to 2007. Science 363, 1193-1199 (2019).

15. Caldeira, K. \& Wickett, M. F. Anthropogenic carbon and ocean pH. Nature 425, 365 (2003).

16. Doney, S. C., Bopp, L. \& Long, M. C. Historical and future trends in ocean climate and biogeochemistry. Oceanography 27, 108-119 (2014).

17. Keeling, R. \& Garcia, H. E. The change in oceanic $\mathrm{O}_{2}$ inventory associated with recent global warming. Proc. Natl Acad. Sci. USA 99, 7848-7853 (2002).

18. Keeling, R. F., Körtzinger, A. \& Gruber, N. Ocean deoxygenation in a warming world. Annu. Rev. Mar. Sci. 2, 199-229 (2010).

19. Stramma, L., and Schmidtko, S. Global evidence of deoxygenation. in Ocean Deoxygenation: Everyone's Problem. (eds Laffoley, D., \& Baxter, J. M.) 25-36 (IUCN, 2019)

20. Gruber, N. Warming up, turning sour, losing breath: ocean biogeochemistry under global change. Philos. Trans. R. Soc. Ser. A 369, 1980-1996 (2011).

21. Doney, S. C., Bopp, L. \& Long, M. C. Historical and future trends in ocean climate and biogeochemistry. Oceanography 27, 108-119 (2014).

22. Garcia, H. E. \& Gordon, L. I. Oxygen solubility in seawater: better fitting equations. Limnol. Oceanogr. 37, 1307-1312 (1992).

23. Levin, L. A. \& Le Bris, N. The deep ocean under climate change. Science $\mathbf{3 5 0}$, 766-768 (2015).

24. Lønborg, C., et al. Temperature dependence of prokaryotic production. Front. Mar. Sci. https://doi.org/10.3389/fmars.2016.00090 (2016).

25. Bednarsek, N., Harvey, C. J., Kaplan, I. C., Feely, R. A. \& Mözma, J. Pteropods on the edge: Cumulative effects of ocean acidification, warming and deoxygenation. Prog. Oceanogr. 145, 1-24 (2016).

26. Stramma, L., Schmidtko, S., Levin, L. A. \& Johnson, G. C. Ocean oxygen minima expansions and their biological impacts. Deep Sea Res. Part I 57, 587-595 (2010).

27. Rabalais, N. N. et al. Eutrophication-driven deoxygenation in the coastal ocean. Oceanography 27, 172-183 (2014).

28. Duarte, C. M. et al. Reconsidering ocean calamities. BioScience 65, 130-139 (2015).

29. Touratier, F., Azouzi, L. \& Goyet, C. CFC- $11, \delta^{14} \mathrm{C}$ and ${ }^{3} \mathrm{He}$ tracers as a means to assess anthropogenic $\mathrm{CO}_{2}$ concentrations in the ocean. Tellus 59B, 318-325 (2007).

30. McKinley, G. A., Fay, A. R., Eddebbar, Y. A., Gloege, L., and Lovenduski, N. S. External forcing explains recent decadal variability of the ocean carbon sink. AGU Adv. https://doi.org/10.1002/essoar.10501723.2 (2020).

31. Stendardo, I. \& Gruber, N. Oxygen trends over five decades in the North Atlantic. J. Geophys. Res. 117, C11004 (2012).

32. Montes, E. et al. Decadal variability in the oxygen inventory of North Atlantic subtropical underwater captured by sustained, long-term oceanographic time series observations. Glob. Biogeochem. Cycles 30, 460-478 (2016).

33. Bates, N. R. Twenty years of marine carbon cycle observations at Devils Hole Bermuda provide insights into seasonal hypoxia, coral reef calcification and 
ocean acidification. Front. Mar. Sci. 4, https://doi.org/10.3389/ fmars.2017.00036 (2017).

34. Krumhardt, K. M., Lovenduski, N. S., Freeman, N. M. \& Bates, N. R. Increasing coccolithophore abundance in the subtropical North Atlantic from 1994 to 2014. Biogeosciences 13, 1163-1177 (2016).

35. Tagklis, F., Ito, T. \& Bracco, A. Modulation of the North Atlantic deoxygenation by the slowdown of the nutrient stream. Biogeosciences 17, 231-244 (2020).

36. Bates, N. R. Interannual variability of oceanic $\mathrm{CO}_{2}$ and biogeochemical properties in the Western North Atlantic subtropical gyre. Deep Sea Res. II 48, 1507-1528 (2001).

37. Bates, N. R. Interannual variability of the oceanic $\mathrm{CO}_{2}$ sink in the subtropical gyre of the North Atlantic Ocean over the last two decades. J. Geophys. Res. (Oceans) 112, C09013 (2007).

38. Bates, N. R. \& Peters, A. J. The contribution of atmospheric acid deposition to ocean acidification in the subtropical North Atlantic Ocean. Mar. Chem. 107, 547-558 (2007).

39. Bates, N. R., Pequignet, A. C., Johnson, R. J. \& Gruber, N. A short-term sink for atmospheric $\mathrm{CO}_{2}$ in subtropical mode water of the North Atlantic Ocean. Nature 420, 489-493 (2002).

40. Bates, N. R. et al. Indicators of anthropogenic carbon dioxide uptake and ocean acidification in the North Atlantic Ocean. Biogeosciences 9, 2509-2522 (2012).

41. Dore, J. E., Lukas, R., Sadler, D. W., Church, M. J. \& Karl, D. M. Physical and biogeochemical modulation of ocean acidification in the central North Pacific. Proc. Natl Acad. Sci. USA 106, 12235-12240 (2009).

42. González-Dávila, M., Santana-Casiano, J. M., Rueda, M. J. \& Llinas, O. The water column distribution of carbonate system variables at the ESTOC site from 1995 to 2004. Biogeosciences 7, 3067-3081 (2010).

43. Yool, A., Oschlies, A., Nurser, A. J. G. \& Gruber, N. A model-based assessment of the TrOCA approach for estimating anthropogenic carbon in the ocean. Biogeosciences 7, 723-751 (2010).

44. Revelle, R. \& Suess, H. Carbon dioxide exchange between atmosphere and ocean and questions of an increase of atmospheric $\mathrm{CO}_{2}$ during the past decades. Tellus 9, 18-27 (1957).

45. Fassbender, A. J., Sabine, C. L. \& Pavesky, H. I. Nonuniform ocean acidification and attenuation of the ocean carbon sink. Geophys. Res. Lett. 44, 8404-8413 (2017).

46. Landschützer, P., Gruber, N., Bakker, D. C. E., Stemmler, I. \& Six, K. D. Strengthening seasonal marine $\mathrm{CO}_{2}$ variations due to increasing atmospheric $\mathrm{CO}_{2}$. Nat. Clim. Change 8, 146-150 (2018)

47. Fabry, V. J., Seibel, B. A., Feely, R. A. \& Orr, J. C. Impacts of ocean acidification on marine fauna and ecosystem processes. ICES J. Mar. Sci. 65, 414-432 (2008).

48. Henson, S. A. et al. Rapid emergence of climate change in environmental drivers of marine ecosystems. Nat. Commun. 8, 14682 (2017).

49. Fry, C., Tyrell, T., Hain, M. P., Bates, N. R. \& Acterberg, E. P. A new method for analyzing processes affecting ocean alkalinity. Mar. Chem. 174, 46-57 (2015).

50. Schroeder, E. \& Stommel, H. How representative is the series of Panulirus stations of monthly mean conditions off Bermuda? Progr. Oceanogr. 5, 31-40 (1969).

51. Knap, A. H. et al. BATS Methods Manual, Version 4 Woods Hole, MA, US. U. S. JGOFS Planning Office $136 \mathrm{pp}$ (1997).

52. Strickland, J. D. H., and Parsons, T. R. A Practical Handbook of Seawater Analysis. (Fisheries Board, Canada, Ottawa, 1968)

53. Zeebe, R. E., and Wolf-Gladrow, D. $\mathrm{CO}_{2}$ in Seawater: Equilibrium, Kinetics, Isotopes. (Elsevier Oceanography Series, 2001).

54. Dickson, A. G., Sabine, C. L., and Christian, J. R. Guide to Best Practices for Ocean $\mathrm{CO}_{2}$ Measurements. (North Pacific Marine Science Organization, Sidney, British Columbia, 2007) PICES Special Publication 3.

55. Millero, F. J. Chemical Oceanography. Fourth Edition. 552 (CRC Press, 2013).

56. Keeling, C. D. Surface ocean $\mathrm{CO}_{2}$. in: Global Carbon Cycle, (ed Heimann, M.) 22-29 (Kluwer Publishers, 1993).

57. Brix, H., Gruber, N. \& Keeling, C. D. Interannual variability of the upper carbon cycle at station ALOHA near Hawaii. Glob. Biogeochem. Cycles 18, GB4019 (2004).

58. Bates, N. R., Michaels, A. F. \& Knap, A. H. Seasonal and interannual variability of oceanic carbon dioxide species at the US JGOFS Bermuda Atlantic Time-series Study (BATS) site. Deep Sea Res. Part II 43, 347-383 (1996).

59. Bates, N. R., Michaels, A. F. \& Knap, A. H. Alkalinity changes in the Sargasso Sea: geochemical evidence of calcification? Mar. Chem. 51, 347-358 (1996).
60. Robbins, L. L., Hansen, M. E., Kleypas, J. A., and Meylan, S. C., (2010). CO2calc: a user-friendly seawater carbon calculator for Windows, Max OS X, and iOS (iPhone), U.S. Geological Survey Open-File Report, 2010-1280, 1-17, http://pubs.usgs.gov/ of/2010/1280/, last access date 15 October 2018, 2010.

61. Mehrbach, C., Culberson, C. H., Hawley, J. E. \& Pytkowicz, R. M. Measurement of the apparent dissociation constants of carbonic acid in seawater at atmospheric pressure. Limnol. Oceanogr. 18, 897-907 (1973).

62. Dickson, A. G. \& Millero, F. J. A Comparison of the equilibrium constants for the dissociation of carbonic acid in seawater media. Deep Sea Res. Part A $\mathbf{3 4}$, 1733-1743 (1987)

63. Dickson, A. G. Standard potential of the reaction: $\mathrm{AgCl}(\mathrm{s})+12 \mathrm{H}_{2}(\mathrm{~g})=\mathrm{Ag}(\mathrm{s})$ $+\mathrm{HCl}(\mathrm{aq})$ and the standard acidity constant of the ion HSO4- in synthetic seawater from 273.15 to 318.15 K. J. Chem. Thermodyn. 22, 113-127 (1990).

64. Lee, K. et al. The universal ratio of boron to chlorinity for the North Pacific and North Atlantic oceans. Geochim. Cosmochim. Acta 74, 1801-1811 (2010).

65. Orr, J. C., Epitalon, J.-M., Dickson, A. G. \& Gattuso, J.-P. Routine uncertainty for the marine carbon dioxide system. Mar. Chem. 207, 84-107 (2018).

66. Touratier, F. \& Goyet, C. Applying the new TrOCA approach to assess the distribution of anthropogenic $\mathrm{CO}_{2}$ in the Atlantic Ocean. J. Mar. Syst. 46, 181-197 (2004).

67. Touratier, F. \& Goyet, C. Definition, properties, and Atlantic distribution of the new tracer TrOCA. J. Mar. Syst. 46, 169-179 (2004).

68. McKinley, G. A. et al. North Pacific carbon cycle response to climate variability on seasonal to decadal timescales. J. Geophys. Res. (Oceans) 111, C07S06 (2006).

\section{Acknowledgements}

The authors would like to acknowledge and thank the numerous principal investigators, researchers, and technicians who have contributed to the time-series projects since their inception. Additional thanks go to the officers and crew of the R/V Weatherbird I, R/V Weatherbird II and R/V Atlantic Explorer. This work was funded by NSF grant OCE1633215 and earlier NSF awards.

\section{Author contributions}

N.R.B. and R.J.J. are principal investigators for the BATS/Hydrostation S projects and coordinate the sampling and analysis of data. Both authors contributed to designing the study and composing the analyses.

\section{Competing interests}

The authors declare no competing interests.

\section{Additional information}

Supplementary information is available for this paper at https://doi.org/10.1038/s43247020-00030-5.

Correspondence and requests for materials should be addressed to N.R.B.

Peer review information Primary handling editors: Heike Langenberg

Reprints and permission information is available at http://www.nature.com/reprints

Publisher's note Springer Nature remains neutral with regard to jurisdictional claims in published maps and institutional affiliations.

Open Access This article is licensed under a Creative Commons Attribution 4.0 International License, which permits use, sharing, adaptation, distribution and reproduction in any medium or format, as long as you give appropriate credit to the original author(s) and the source, provide a link to the Creative Commons license, and indicate if changes were made. The images or other third party material in this article are included in the article's Creative Commons license, unless indicated otherwise in a credit line to the material. If material is not included in the article's Creative Commons license and your intended use is not permitted by statutory regulation or exceeds the permitted use, you will need to obtain permission directly from the copyright holder. To view a copy of this license, visit http://creativecommons.org/ licenses/by/4.0/.

(c) The Author(s) 2020 